\title{
Etika Kedokteran dalam Kegiatan Tanggap Darurat Bencana
}

\author{
R Sjamsuhidajat ${ }^{\mathrm{T}}$, Putri Dianita Ika Meilia ${ }^{\mathrm{I}, 2}$, Itsna Arifatuz Zulfiyah \\ ${ }^{\mathrm{I}}$ Majelis Kehormatan Etik Kedokteran Pengurus Besar Ikatan Dokter Indonesia \\ ${ }^{2}$ Instalasi Kedokteran Forensik dan Pemulasaraan Jenazah, Rumah Sakit Umum Pusat Persahabatan, Jakarta
}

\author{
Kata Kunci \\ Etika, tanggap darurat bencana, triase, \\ informed consent, penjatahan sumber \\ daya \\ Korespondensi \\ antalya22ftf@gmail.com \\ Publikasi \\ (C) 2020 JEKI/ilmiah.id \\ DOI \\ I0.26880/jeki.v4ii.39 \\ Tanggal masuk: Io November 2019 \\ Tanggal ditelaah: II Januari 2020 \\ Tanggal diterima: 10 Februari 2020 \\ Tanggal publikasi: 24 Februari 2020
}

\begin{abstract}
Abstrak Bencana dapat menghancurkan satu negara dalam waktu singkat, baik karena kerusakan struktur maupun wabah penyakit yang diakibatkan setelahnya. Indonesia merupakan salah satu negara yang paling rentan terhadap bencana, baik bencana yang disebabkan oleh faktor alam maupun faktor manusia. Untuk mencegah dan mengurangi kerusakan yang disebabkan oleh bencana, Indonesia membutuhkan sistem penanggulangan bencana yang kokoh. Berbagai dilema etik sering kali muncul dalam penanggulangan bencana ini. Beberapa dilema etik yang paling menonjol di Indonesia antara lain dilema dalam triase, melakukan riset, meminta informed consent, memberikan pelayanan dalam sarana yang terbatas, serta melindungi keselamatan dan kesehatan tenaga medis yang membantu korban bencana sesuai Konvensi Jenewa.
\end{abstract}

\begin{abstract}
Disasters can destroy a country in a short amount of time, both due to structural damage and the subsequent outbreaks of diseases. Indonesia is one of the countries that are the most vulnerable to disasters, both natural as well as man-made disasters. To prevent and reduce damage caused by disasters, Indonesia needs a robust disaster management system. Various ethical dilemmas can arise in disaster management. Some of the most prominent ethical dilemmas in Indonesia include dilemmas in triaging processes, conducting research in disaster settings, obtaining informed consent, providing services in limited-resource settings, and protecting the safety and health of medical personnel who assist victims of disasters in accordance with the Geneva Conventions.
\end{abstract}

Indonesia merupakan salah satu negara yang paling rentan terhadap bencana, baik bencana yang disebabkan oleh faktor alam (natural disaster) atau faktor manusia (man-made disaster), maupun campuran dari kedua faktor tersebut. Satu bencana alam terbesar yang pernah terjadi di Indonesia adalah tsunami di Sumatra pada tahun 2004. Laporan dari Harian Kompas (29/12/2004) menyebutkan bahwa tsunami ini menimbulkan sekitar 230.000 orang tewas di 14 negara, dengan 170.000 korban di antaranya yang timbul di Indonesia. Sedangkan bencana yang disebabkan oleh faktor manusia contohnya kecelakaan maut dua kereta api pada Tragedi Bintaro pada tahun 1987. Majalah Tempo (19/10/1987) melaporkan bahwa tragedi ini menyebabkan 156 orang tewas dan lebih dari 300 orang lainnya lukaluka. Sementara itu, pada bencana banjir yang terjadi pada awal tahun 2020 di daerah Jakarta dan sekitarnya, seperti dilansir oleh Merdeka. com (03/01/2020), diduga bahwa baik faktor alam maupun manusia turut berperan.

Dalam Undang-undang Republik Indonesia Nomor 24 Tahun 2007, bencana didefinisikan sebagai rangkaian peristiwa yang dapat mengancam dan mengganggu kehidupan manusia, yang dapat disebabkan oleh faktor alam, non-alam, dan/atau manusia sehingga menyebabkan timbulnya korban jiwa, kerusakan lingkungan, dampak psikologis, dan kerugian harta benda. ${ }^{1}$ Jumlah kejadian bencana di Indonesia selama 10 tahun terakhir terus mengalami peningkatan, dengan jumlah 
terbanyak pada tahun 2017 - 2018. Oleh karena itu, setiap negara membutuhkan sistem penanggulangan bencana yang kokoh untuk mencegah dan mengurangi kerusakan yang disebabkan oleh bencana. Sistem penanggulangan bencana ini dapat dibedakan menjadi penanggulangan bencana berskala internasional, nasional, dan lokal. ${ }^{2,3}$

Sistem penanggulangan bencana pada skala internasional diatur pada Kerangka Aksi Hyogo (KAH) yang mengidentifikasi 5 prioritas untuk sektor kesehatan yang harus dilakukan untuk menguatkan ketahanan negara terhadap bencana. Lima prioritas tersebut adalah: (1) pengurangan risiko bencana, (2) penilaian risiko bencana dan peningkatan peringatan dini, (3) penggunaan budaya, inovasi, dan pendidikan, (4) reduksi faktor risiko yang mendasari, dan (5) penguatan kesiapan bencana untuk respons dan pemulihan yang efektif. ${ }^{3}$ Sistem penanggulangan bencana merupakan bentuk kerja multisektor, dimana kesehatan turut memegang peranan penting di dalamnya. ${ }^{1,2}$

Sistem penanggulangan bencana ini dibagi menjadi beberapa tahap, yaitu (1) tahap mitigasi, (2) tahap persiapan (preparedness), (3) tahap respons, dan (4) tahap pemulihan. ${ }^{4}$ Masalah etika dapat terjadi pada setiap tahapan ini. Dalam artikel ini akan dibahas beberapa masalah etika kedokteran yang kerapkali muncul di Indonesia agar dapat menjadi panduan bagi dokter yang terlibat dalam kegiatan tanggap darurat bencana.

\section{Etika dalam Setiap Tahap Penanggulangan Bencana}

\section{Etika pada tahap mitigasi}

Mitigasi terdiri dari sejumlah aktivitas yang dapat mengurangi probabilitas kejadian bencana atau mengurangi efek bencana yang tidak dapat dicegah. Tenaga kesehatan, bekerja sama dengan pemerintah, memiliki peran dalam membuat kebijakan publik pada tahap ini, misalnya dengan membuat program imunisasi, mengontrol vektor penyakit, program keluarga, sanitasi lingkungan, dan sebagainya. ${ }^{4}$ Salah satu contoh dilema etik dalam tahap ini adalah program imunisasi, yang lebih bertujuan memproteksi publik dari bahaya dibandingkan dengan menghormati asas autonomi individu. Oleh karena itu, rasio risiko dibanding keuntungan pada setiap program imunisasi harus dihitung dengan tepat. ${ }^{5}$

\section{Etika pada tahap persiapan}

Tahap persiapan pada penanggulangan bencana terdiri atas pembuatan program penanggulangan bencana, sistem peringatan dini, sistem komunikasi emergensi, latihan dan rencana evakuasi, inventarisasi sumber daya, dan edukasi publik. Tujuan tahap ini adalah untuk menyiapkan respons terhadap segala bentuk bencana secara tepat dan tanggap. Pada fase ini, tenaga kesehatan juga memiliki peran dalam menyediakan informasi mengenai kesehatan dan nutrisi yang berkontribusi dalam sistem peringatan dini pada semua sektor. ${ }^{4}$ Salah satu dilema etik yang dapat terjadi pada tahap ini adalah ketika dokter harus menentukan alokasi sumber daya. Sumber daya ini dapat berupa makanan, peralatan, air, obat, dan segala benda esensial kehidupan lainnya. Dalam hal ini, dokter mungkin harus mengutamakan prinsip keadilan (justice) dibandingkan dengan asas autonomi individu pasien. ${ }^{5}$

\section{Etika pada tahap respons}

Setiap dokter dan tenaga medis harus senantiasa memegang empat prinsip etika utama, yaitu beneficence, non-maleficence, autonomy, dan justice dalam tahap respons bencana. Masalah etika yang dapat muncul pertama kali adalah mencari cara untuk mobilisasi ke lokasi bencana secepat mungkin sementara akses untuk ke lokasi tersebut dapat membahayakan jiwa dokter dan petugas penanggulangan bencana lainnya. Masalah selanjutnya terjadi pada saat melakukan triase, sistem yang memaksa dokter harus membagi pasiennya sesuai prioritas dan memilih urutan perawatan sesuai dengan prioritas tersebut. Masalah ini dapat diperberat dengan kondisi bencana yang mungkin tidak ideal, baik akibat kurangnya tenaga medis yang dikirimkan atau karena kurangnya jumlah obat yang tersedia. ${ }^{5}$

Etika pada tahap pemulihan

Semua nilai dan prinsip etika yang telah 
disebutkan pada tahap sebelumnya harus tetap diperhatikan pada tahap pemulihan ini. Akan tetapi, setiap dokter harus bekerja secara profesional sesuai dengan kebutuhan yang mungkin baru muncul setelah bencana terjadi. Pada periode ini, kebutuhan dari korban yang selamat harus menjadi perhatian. Korban bencana dapat kehilangan keluarga dan mengalami berbagai masalah psikologis, sehingga pendekatan pasien pada tahap ini harus melibatkan berbagai sektor secara holistik. $^{5}$

\section{Beberapa Masalah Etika dalam Penanggulangan Bencana}

Ada begitu banyak dilema etis yang ditemukan dalam penanggulangan bencana. Tabel 1 menunjukkan berbagai tantangan etika dalam kedokteran tanggap bencana menurut Larkin. $^{6}$

Berikut ini akan dibahas mengenai beberapa masalah etika yang menonjol di Indonesia:

\section{Melakukan triase secara cepat dan tepat}

Triase merupakan salah satu tahap terpenting dalam penanggulangan bencana. Triase membagi pasien dalam empat kelompok, yaitu merah (gawat darurat), kuning (urgen), hijau (luka ringan), dan hitam (korban meninggal). Triase dalam bencana dilakukan untuk mengelompokkan korban bencana berdasarkan tingkat keparahan yang diderita setalah terjadinya bencana, menolong korban bencana sebanyak-banyaknya, memberikan pertolongan pertama korban bencana sesuai kebutuhan, dan meningkatkan kesempatan hidup korban bencana. Hingga saat ini, terdapat banyak sistem triase yang diperkenalkan untuk penilaian awal korban bencana di lokasi, seperti START, SIEVE, triase Homebush, dan sebagainya. ${ }^{2,7}$

Pada tahap ini, tenaga medis harus berfokus pada dua prinsip bioetika: beneficence dan justice. Menurut World Medical Association (WMA) Statement on Medical Ethics in the Event of Disasters pada tahun 1994, pertimbangan seorang dokter mengenai pasien mana yang harus diselamatkan terlebih dahulu hanya boleh didasarkan atas status medis, bukan atas kriteria non-medis yang lain. ${ }^{3}$ Hal ini juga dijelaskan dalam Kode Etik Kedokteran Indonesia (KODEKI) Tahun 2012 pasal 10 yang menyebutkan bahwa setiap dokter wajib menghormati hak pasiennya, termasuk hak memperoleh pelayanan medis dan perawatan. Dalam penjelasan pasal disebutkan bahwa setiap dokter harus memberikan pengobatan pada pasien tanpa melihat ras, agama, suku, kedudukan sosial, kondisi kecacatan tubuh, ataupun status kemampuan membayarnya. ${ }^{8}$

Selain itu, prinsip justice juga sangat berperan dalam kondisi bencana. Sumber daya kesehatan yang pada situasi normal juga umumnya sudah terbatas (scarce) akan bertambah langka. Hal ini dapat disebabkan baik karena kerusakan atau kehancuran fasilitas layanan kesehatan maupun akibat tenaga kesehatan yang turut terkena dampak dari bencana, terutama pada kejadian bencana alam yang berskala besar. Berdasarkan prinsip justice ini, para korban bencana yang paling terkena dampak seharusnya memperoleh prioritas utama. Namun, dengan adanya proses triase, maka layanan kedokteran dan kesehatan harus juga mempertimbangkan prinsip rationing, yaitu bertujuan untuk memberikan "the greatest good for the greatest number". Dengan memberlakukan prinsip ini maka mungkin tidak semua korban akan dapat menerima tingkat prioritas layanan yang sama, namun disesuaikan dengan tujuan memaksimalkan manfaat bagi masyarakat luas. ${ }^{9-}$ 11

Melakukan riset dan meminta informed consent pada korban bencana

Kondisi bencana pada dasarnya menyediakan kesempatan yang sangat berharga untuk pembelajaran, baik terkait akibat dari bencana itu sendiri maupun terkait penanganan atau kegiatan tanggap darurat bencana. Oleh karena itu, kesempatan yang ada hendaknya digunakan dengan sebaik-baiknya melalui kegiatan penelitian yang baik. Namun, pelaksanaan penelitian dalam kondisi bencana menimbulkan potensi dilema etik. Salah satu hal yang harus diperhatikan adalah masalah informed consent penelitian. Korban bencana pada dasarnya sedang berada dalam tekanan 


\section{Tabel 1. Tantangan etika dalam kedokteran tanggap bencana ${ }^{6}$}

Level Mikro (provider-patient)

1 Peduli pada pasien dengan gangguan kecemasan atau pasien yang membutuhkan perhatian khusus lainnya

2 Menyeimbangkan kebutuhan perawatan paliatif dengan permintaan keluarga pasien untuk "melakukan segalanya"

3 Peduli pada warga negara asing, tenaga militer, tawanan, atau pelaku teror

4 Memprioritaskan perawatan "VIP," pegawai negeri, pemimpin, keluarga, teman, dan petugas kesehatan

5 Menjaga privasi korban di dalam suasana ramai, situasi pengawasan, karantina, dan terhadap sorotan media massa

6 Melaporkan dan mengawasi kebutuhan yang mempengaruhi kebebasan dan kerahasiaan pasien

7 Melakukan penelitian dan mendapatkan informed consent korban bencana

8 Merawat korban yang terkontaminasi, memiliki penyakit menular, atau bekerja di lingkungan dengan ancaman kesehatan lainnya

9 Melakukan triase secara cepat, objektif, akurat, dan sesuai etika dalam waktu dan dengan informasi yang terbatas

10 Memenuhi standar pelayanan dengan sarana dan prasarana yang terbatas

11 Menyeimbangkan peran penyedia layanan primer dengan peran sebagai agen kesehatan masyarakat

12 Menyeimbangkan tugas terhadap pasien secara individu dengan tugas untuk menjaga diri dan keluarga di antara kerusakan infrastruktur, pandemik influenza, dan ancaman bencana lainnya

13 Menyeimbangkan integritas dengan empati terhadap korban individu yang mencari kompensasi atas kerusakan dan disabilitas

Level Meso (provider-provider)

1 Membantu kolega, petugas kesehatan publik, dan staf kesehatan, walaupun dalam pengerjaannya dapat membahayakan nyawa diri sendiri

2 Pertukaran peran, benturan kekuasaan, dan kesalahpahaman antar tenaga kesehatan dalam segala hierarki

3 Berhadapan dengan kelalaian dan sikap tidak profesional baik dari pemimpin atau bawahan

4 Keselamatan dan kesehatan fisik dan mental pegawai sebelum, ketika, dan setelah serangan teror

5 Kesehatan kerja, kebutuhan melapor, dan privasi

6 Mengoptimalkan komunikasi di antara pemberi respons pertama, konsultan, organisasi, dan staf penyedia pelayanan kesehatan dalam semua level

7 Konflik kebutuhan dalam dan di antara organisasi yang merebutkan sumber pendanaan lokal, nasional, dan internasional

8 Memperhatikan kesehatan mental, keselamatan, dan kesejahteraan diri sendiri dan penyedia pelayanan kesehatan lainnya

9 Menyeimbangkan perekrutan tenaga kerja terampil dari tenaga relawan

10 Menentukan bagaimana respons bencana dengan menyeimbangkan sisi altruism dan tugas profesional, atau keduanya

11 Memastikan bahwa pekerjaan bencana diakui dan diberikan kompensasi secara adil oleh pimpinan

12 Menentukan bagaimana relawan diberikan sertifikat pelatihan dan bagaimana mereka tetap bertanggung jawab

13 Menerima perintah kerja suka rela tanpa adanya imbalan, jaminan, atau kontrol

\begin{tabular}{ll}
\hline Level Makro (provider-society) \\
\hline 1 & Menentukan kerja dan batasan dari penanganan bencana, baik yang berasal dari lokal, domestik, luar negeri, atau global \\
2 & Kemauan organisasi untuk merespon secara altruistik kepada bencana versus tugas untuk membayar tagihan organisasi \\
3 & Memastikan keadilan dan meminimalkan konflik kebutuhan dalam mengalokasikan sumber daya \\
4 & Tugas untuk mendukung latihan persiapan yang valid, program vaksinasi, dan kelompok relawan \\
5 & Menolak kebijakan laporan yang tidak etis, serta diskriminasi etnis dan agama \\
6 & Tugas untuk berkomunikasi secara jujur dan hati-hati untuk risiko pembuat kebijakan lokal dan negara, media, serta masyarakat \\
7 & Promosi aktif evaluasi yang mengenai kebijakan penelitian terhadap masyarakat yang terdampak bencana \\
8 & Membangun protokol yang transparan untuk triase yang sesuai etika, serta aktivasi, pemeliharaan, dan terminasi rencana tang- \\
& gap darurat bencana \\
9 & Bekerja secara domestik atau internasional dengan sumber daya yang terbatas \\
\hline
\end{tabular}


karena mengalami masalah baik kesehatan, mental, sosial, maupun material, sehingga dapat dianggap tidak dapat memberikan persetujuan secara bebas sebagaimana yang dapat diberikan dalam kondisi non bencana (under duress). Selain itu, telaah usulan penelitian juga mungkin sulit dilakukan seperti seharusnya karena otoritas lokal juga sedang mengalami disrupsi kegiatan akibat bencana. Hal ini rentan menimbulkan isu etis, terutama apabila penelitian menggunakan subjek manusia dan melibatkan peneliti asing. Oleh karena itu, penelitian dalam kondisi bencana sedapat mungkin harus tetap melalui proses telaah etika penelitian dan dinyatakan lolos kaji etik oleh otoritas lokal (ethical review), terutama apibila akan dipublikasi secara luas. ${ }^{12}$ Hal ini sesuai dengan KODEKI Tahun 2012 pasal 6 yang menyebutkan bahwa setiap dokter yang melakukan penelitian harus mengikuti kaidah yang telah ditentukan. ${ }^{8}$

Informed consent mengenai intervensi medis juga merupakan salah satu dilema etik dalam penanganan bencana. Dilansir dari WMA Declaration of Lisbon on the Rights of Patient pada tahun 1981, dikatakan bahwa apabila pasien tidak sadar atau tidak mampu menunjukkan keinginannya, maka informed consent harus didapatkan dari keluarga atau yang mewakili. Hal ini juga sesuai dengan prinsip autonomi. Dalam KODEKI Tahun 2012 pasal 5 juga disebutkan bahwa setiap perbuatan dokter yang dapat melemahkan daya tahan psikis maupun fisik pasien wajib memperoleh persetujuan dari pasien atau keluarganya. Apabila keluarga tidak ada sementara intervensi medis harus segera dilakukan, maka pasien dianggap setuju menerima intervensi, kecuali apabila pada situasi yang sama sebelumnya pasien memilih untuk menolak intervensi. ${ }^{5,8}$

Akan tetapi, menurut WMA tidak akan ada waktu yang cukup untuk meminta persetujuan tindakan kepada pasien pada kondisi darurat seperti yang terjadi pada bencana. Pada kondisi seperti ini, dokter diminta untuk lebih memprioritaskan prinsip bioetika non-maleficence dibandingkan dengan autonomi. Walaupun dokter diyakini telah berusaha memilih keputusan yang terbaik demi kelangsungan hidup pasien, beberapa korban bencana masih dapat menolak intervensi yang dilakukan. Dalam situasi ini, kesehatan mental korban harus dievaluasi. Apabila kesehatan mental korban diragukan, intervensi harus tetap dilanjutkan untuk mencegah terjadinya komplikasi medis lebih lanjut. Apabila evaluasi menunjukkan bahwa mental korban baik, maka korban harus dibujuk untuk menerima intervensi. ${ }^{5}$

Sebagaimana dalam praktik kedokteran sehari-hari, beberapa korban bencana yang mengalami cedera berat dapat meminta euthanasia. Saat ini, euthanasia telah dilarang dalam hukum internasional publik dan sebagian besar kode etik kedokteran di berbagai penjuru dunia. Dalam KODEKI Tahun 2012 pasal 11 juga disebutkan bahwa setiap dokter harus mengingat kewajiban dirinya dalam melindungi makhluk insani. Dalam penjelasan pasal disebutkan bahwa dokter dilarang melibatkan diri atau terlibat dalam euthanasia. Dokter diwajibkan untuk mengerahkan segala kemampuannya untuk meringankan penderitaan hidup, tapi tidak mengakhirinya. ${ }^{5,8}$

Menjaga standar pelayanan dalam sarana dan prasarana yang terbatas

Walaupun WHO telah menerbitkan panduan untuk kesiapan pelayanan kesehatan dalam kondisi bencana, sebagaimana tercantum dalam Hospital Preparedness for Emergencies (HOPE), kondisi terburuk sering kali tidak dapat dihindari. Menurut WMA, setiap tenaga kesehatan harus memastikan bahwa penanganan korban bencana harus sesuai dengan prinsip etika paling minimal. Di tengah kericuhan bencana yang membutuhkan banyak bantuan, sumber daya yang tersedia seringkali berjumlah sangat terbatas. Di sisi lain, semua petugas penanggulangan bencana akan berusaha melakukan segalanya demi memberikan bantuan yang maksimal sekalipun pada lingkungan yang tidak familiar. Petugas kesehatan setempat juga mungkin terkena dampak bencana sehingga tidak dapat bekerja secara optimal. Kondisi ini kemudian menyebabkan timbulnya berbagai dilema etik. Oleh karena itu, setiap dokter yang bertugas harus memegang penuh prinsip beneficence 
dan justice, dengan sekaligus memperhatikan autonomi pasien pada tahapan ini. ${ }^{13}$

Dalam penjelasan KODEKI Tahun 2012 pasal 2 disebutkan bahwa setiap dokter wajib memperjuangkan dipenuhinya fasilitas, sarana, dan prasarana yang sesuai dengan pendoman nasional pelayanan kedokteran. Faktanya, kondisi bencana sering kali tidak ideal dengan standar minimal pelayanan kedokteran, baik karena kurangnya tenaga kesehatan yang dikirim atau karena kurangnya obat yang tersedia. Oleh karena itu, pada pasal yang sama juga disebutkan bahwa dalam situasi dimana fasilitas pelayanan kesehatan tidak optimal, pengambilan keputusan profesional wajib dilakukan dengan disertai perilaku profesional terbaik dokter demi kepentingan terbaik pasien. $^{8}$

\section{Keselamatan dan kesehatan tenaga medis}

Dokter dan tenaga medis lainnya merupakan salah satu sumber daya manusia terpenting dalam penanggulangan bencana. Di sisi lain, mereka juga dapat menerima dampak negatif dari kondisi bencana, seperti wabah pandemi, polusi lingkungan, dan konflik militer. Kondisi ini dapat menjadi ancaman bagi keselamatan dan kesehatan dokter. KODEKI Tahun 2012 pasal 20 mengatakan bahwa setiap dokter wajib selalu memelihara kesehatannya untuk memastikan bahwa dirinya tetap layak praktik. Pasal ini mungkin dapat menjadi alasan adanya dilema etika seorang dokter dalam menentukan batasan penanganan korban bencana di kondisi yang mengancam, terutama mengingat bahwa bencana merupakan kondisi yang berbeda jika dibandingkan dengan kondisi praktik kedokteran sehari-hari. Saat bencana, berkurangnya satu dokter akan memiliki dampak berat dalam berlangsungnya penanggulangan bencana. ${ }^{6,8}$

Dalam penjelasan KODEKI Tahun 2012 pasal 8 disebutkan bahwa dokter tidak hanya bertanggung jawab kepada pasien dan dirinya sendiri, namun juga kepada teman sejawat. Untuk menjadi seorang dokter yang profesional, dokter harus dapat memenuhi ketiga tanggung jawab ini tanpa terkecuali. Kewajiban ini juga disebutkan dalam pasal 18 yang mengatakan bahwa setiap dokter wajib memperlakukan teman sejawatnya sebagaimana ia sendiri ingin diperlakukan. Dalam penjelasan pasal disebutkan bahwa setiap dokter wajib menegakkan budaya tolong menolong dengan teman sejawatnya. Setiap dokter harus menyadari bahwa reputasi dirinya dapat terbentuk akibat pengorbanan teman sejawat di satu lingkungan fasilitas pelayanan kesehatan yang sama. Dengan demikian, dapat disimpulkan bahwa setiap dokter juga bertanggung jawab akan kesehatan fisik, mental, dan sosial teman sejawatnya. ${ }^{8}$

Dalam tataran institusi maupun organisasi, harus dilakukan pengaturan beban kerja agar layanan tetap berjalan secara optimal walaupun ada sebagian dokter dan tenaga kesehatan yang diberangkatkan ke daerah bencana. Dokter dan tenaga kesehatan yang tetap melakukan pelayanan di institusi asalnya hendaknya dapat mengambil alih tugas teman sejawatnya dan juga mendapatkan penghargaan yang layak. Pemimpin institusi hendaknya memahami bahwa dalam kondisi bencana, pembagian tugas mungkin harus disiasati agar dapat menunjang kegiatan tanggap bencana namun tetap tidak merugikan pasien. ${ }^{6}$

\section{Rencana penanggulangan bencana nasional}

Sektor kesehatan merupakan salah satu sektor yang dapat terdampak cukup luas pada kondisi bencana, terutama bencana alam yang berskala besar. Oleh karena itu, diperlukan rencana tanggap darurat bencana dalam bidang kesehatan yang komprehensif. Seorang dokter dapat turut berperan menyusun rencana tersebut melalui organisasi profesi dalam bidangnya masing-masing dengan bekerja sama dan berkoordinasi dengan organisasi dari sektor dan bidang lainnya. Prinsip utama yang harus dijunjung dalam penyusunan rencana tersebut adalah prinsip humanitarian, tanpa ada "udang di balik batu". Artinya, segala jenis bantuan dan kegiatan tanggap darurat bencana yang direncanakan tidak boleh disalahgunakan untuk kepentingan politik, agama, ataupun lainnya. ${ }^{6}$ Hal ini sesuai dengan KODEKI Tahun 2012 pasal 13 yang menyebutkan bahwa setiap dokter harus dapat bekerjasama dengan berbagai pihak lintas sektoral di bidang kesehatan ataupun 
bidang lainnya. ${ }^{8}$

Semua dokter harus menyadari bahwa dalam kondisi bencana, terutama bencana alam yang berskala luas, semua memiliki kewajiban untuk turut membantu sesuai kompetensi masing-masing bila diperlukan. Agar dapat berperan aktif dalam kegiatan tanggap darurat bencana, sebaiknya topik tentang kedokteran tanggap bencana dimasukkan dalam kurikulum fakultas kedokteran. Sebuah penelitian mendapatkan bahwa pembahasan tentang kedokteran tanggap bencana yang dilakukan selama 2 minggu dirasakan bermanfaat bagi mahasiswa kedokteran. Muatan dari kurikulum kedokteran tanggap bencana harus disesuaikan dengan profil bencana di wilayah tersebut. ${ }^{14}$

\section{Identifikasi korban meninggal akibat bencana}

Walaupun seseorang sudah meninggal dunia, tetapi harus tetap dihormati martabatnya selaku manusia, atau yang disebut dengan residual dignity. Salah satu upaya dalam menjaga residual dignity ini adalah dengan melakukan identifikasi dengan metode disaster victim identification (DVI) sesuai dengan standar internasional. Tujuannya adalah agar jenazah dapat dikembalikan ke keluarga, semua urusan hukum administratifnya dapat diselesaikan, dan dimakamkan sesuai dengan tuntunan agama dan kultural yang dianutnya. Hal ini sesuai dengan KODEKI Tahun 2012 pasal 8 yang menyebutkan bahwa setiap dokter, dalam praktik medisnya, wajib memberikan penghormatan atas martabat manusia. Selain itu, karena proses DVI melibatkan banyak komponen dan personil inter sektoral, maka dokter yang terlibat harus mampu bekerja sama dengan profesional sesuai dengan kompetensi dan kewenangan masing-masiang, sesuai dengan pasal 13 KODEKI Tahun 2012.8,9

\section{KESIMPULAN}

Setiap dokter harus memahami sistem penanggulangan bencana dan perannya dalam setiap tahap penanggulangan bencana. Adanya berbagai isu dan dilema etik kedokteran yang berpotensi timbul dalam pelaksanaan kegiatan tanggap darurat bencana harus dapat diantisipasi dan diatasi dengan baik. Untuk itu diperlukan adanya integrasi topik kedokteran tanggap bencana ke dalam kurikulum kedokteran.

\section{KONFLIK KEPENTINGAN}

Penulis tidak memiliki konflik kepentingan dalam penulisan artikel ini.

\section{REFERENSI}

1. Undang-undang Republik Indonesia Nomor 24 Tahun 2007 tentang Penanggulangan Bencana.

2. Pedoman teknis penanggulangan krisis kesehatan akibat bencana: panduan bagi petugas kesehatan yang bekerja dalam penanganan krisis kesehatan akibat bencana di Indonesia. Jakarta: Departemen Kesehatan RI; 2007.

3. World Health Organization. Disaster risk management for health: overview. Geneva: WHO; 2011.

4. Wisner B, Adams J, World Health Organization. Environmental health in emergencies and disasters: A practical guide. WHO; 2002.

5. Karadag CO, Hakan AK. Ethical dilemmas in disaster medicine. Iran Red Crescent Med J. 2012; 14(10):602-12.

6. Larkin GL. Ethical Issues in Disaster Medicine. In: Koenig KL, Schultz CH, editors. Koenig and Schultz's Disaster Medicine: Comprehensive Principles and Practices. Cambridge: Cambridge University Press; 2009. p. 62-74.

7. Christ M, Grossmann F, Winter D, Bingisser R, Platz E. Modern triage in the emergency department. Dtsch Arztebl Int. 2010; 107(50):892-8.

8. Kode etik kedokteran Indonesia tahun 2012. Jakarta: 2012.

9. Byard RW, Winskog C. Potential problems arising during international disaster victim identification (DVI) exercises. Forensic Sci 
Med Pathol. 2010; 6:1-2.

10. Bagherzadeh N. Death in disaster: actions and attitudes towards dead body management after disasters in Yogyakarta. IFHV Work Paper. 2014; 4(2):

11. Ali H, Brown N, Chiro L, Dillinger E, Droder E, Hanby J, et al. Recovery and identification of the missing after disaster: case studies, ethical guidelines and policy recommendations.

12. Lo STT, Chan EYY, Chan GKW, Murray V, Abrahams J, Ardalan A, et al. Health emergency and disaster risk management (health-EDRM): developing research field within the Sendai Framework paradigm. Int J Disaster Risk Sci. 2017; 8:145-9.

13. Aung KT, bt Abdul Rahman N'I, Nurumal MS, Ahayalimudin NA. Ethical disaster or natural disaster? Importance of ethical issue in disaster management. J Health Sci Nurs. 2017; 6(2):90-3.

14. Kaji AH, Coates W, Fung CC. A disaster medicine curriculum for medical students. Teach Learn Med. 2010; 22(2):116-22. 